\title{
Revisiting the $\mathrm{CO}_{2}$ "source" problem in upwelling areas - a comparative study on eddy upwellings in the South China Sea
}

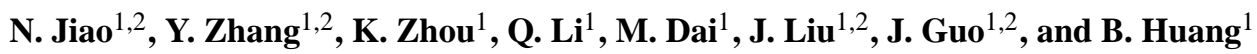 \\ ${ }^{1}$ State Key Laboratory of Marine Environmental Sciences, Xiamen University, Xiamen 361101, China \\ ${ }^{2}$ Institute of Marine Microbes and Ecospheres, Xiamen University, Xiamen 361101, China
}

Correspondence to: N. Jiao (jiao@xmu.edu.cn)

Received: 31 July 2013 - Published in Biogeosciences Discuss.: 13 August 2013

Revised: 12 March 2014 - Accepted: 14 March 2014 - Published: 6 May 2014

\begin{abstract}
The causes for a productive upwelling region to be a source of $\mathrm{CO}_{2}$ are usually referred to the excess $\mathrm{CO}_{2}$ supplied via upwelling of high dissolved inorganic carbon (DIC) from deep water. Furthermore, we hypothesize that microbial activity plays a significant role on top of that. To test this hypothesis, multiple biogeochemical parameters were investigated at two cyclonic-eddy-induced upwelling sites, CE1 and CE2, in the western South China Sea. The data showed that upwelling can exert significant influences on biological activities in the euphotic zone and can also impact on particulate organic carbon (POC) export flux depending on upwelling conditions, such as the magnitude, timing, and duration of nutrient input and consequent microbial activities. At CE2, the increase of phytoplankton biomass caused by the upwelled nutrients resulted in increase of POC export flux compared to non-eddy reference sites, while at CE1 the microbial respiration of organic carbon stimulated by the upwelled nutrients significantly contributed to the attenuation of POC export flux. These results suggest that on top of upwelled DIC, microbial activities stimulated by upwelled nutrients and labile organic carbon produced by phytoplankton can play a critical role for an upwelling area to be outgassing or uptaking $\mathrm{CO}_{2}$. We point out that even though an upwelling region is outgassing $\mathrm{CO}_{2}$, carbon sequestration still takes place through the POC-based biological pump as well as the refractory dissolved organic carbon (RDOC)-based microbial carbon pump.
\end{abstract}

\section{Introduction}

Upwelling is an oceanographic phenomenon that can bring nutrient- and dissolved inorganic carbon (DIC)-rich sub-thermocline water upwards and thus can lead to ecosystem biogeochemical responses (Mann and Lazier, 2006). Cyclonic eddies elevate isopycnals in the upper ocean to induce upwelling-like motion to varying degrees (Sweeney et al., 2003), and thus provide diverse scenarios for studies on subsequent biogeochemical responses. Note that here we term in a broad sense the eddy-induced upward motion as upwelling. Some studies have reported eddy-induced upwelling areas to be sinks of atmospheric $\mathrm{CO}_{2}$ associated with enhanced export flux of particulate organic carbon (POC) (Beaulieu, 2002; Honjo et al., 1999; McGillicuddy et al., 1998, 2003; Newton et al., 1994; Siegel et al., 1999; Benitez-Nelson et al., 2007; O'Brien et al., 2013). Other studies suggest that eddies make a minor contribution to regional biogeochemical budgets (Oschlies and Garçon, 1998; Oschlies, 2002), and upwelling areas can be $\mathrm{CO}_{2}$ outgassing (Rosón et al., 1999; Chen et al., 2007). The recognized fact is that upwelled DIC-rich deep water through isopycnals elevation could release $\mathrm{CO}_{2}$ and ultimately result in outgassing (Burt et al., 2013). However, microbial contributions to such outgassing have not yet been fully elucidated.

Phytoplanktonic community structure shifts were reported to be of great importance in controlling POC-based biological pump (BP) carbon export from the surface ocean (Archer, 1995; Michaels and Silver, 1988; Boyd and Newton, 1999). When small-sized phytoplankton (e.g., Prochlorococcus and Synechococcus) dominate the community, the BP would not be remarkable because picoplankton POC sinking rates are 
extremely low (Takahashi and Bienfang, 1983) unless they are aggregated (Richardson and Jackson, 2007). Instead, they are effectively grazed by Protozoa within the microbial loop (Azam et al., 1983; Glover et al., 1988). Eddy lifespan is another controlling factor on the extents of biological response and associated export flux, as nutrient injection would subside as the eddy begins to decay (Sweeney et al., 2003). Despite these significant recognitions, one issue has not yet been elucidated: While eddy-induced nutrient supply to surface waters increases primary production, elevated nutrient levels and consequently enhanced primary production could also stimulate microbial heterotrophic metabolisms that influence carbon respiration (Jiao et al., 2011) as well as carbon sequestration through the microbial carbon pump (MCP) (Jiao et al., 2010). Given that microbes are major contributors to both community respiration $\left(\mathrm{CO}_{2}\right.$ source $)(\sim 50$ to $>90 \%$; Rivkin and Legendre, 2001; Robinson and Williams, 2005) and refractory dissolved organic carbon (RDOC) $\left(\mathrm{CO}_{2}\right.$ sink) as the output of the MCP (Benner and Herndl, 2011), microbial activities remain the key aspect to be addressed in this regard. We therefore hypothesize that upwelling can either increase or decrease POC export flux depending on the environmental conditions and nature of microbial activity, and thus can significantly influence the dynamics of air-sea $\mathrm{CO}_{2}$ exchanges. To test and verify this hypothesis, we conducted a comparative study with systematic biogeochemical observations in two comparable cyclonic eddies in the South China Sea (SCS) simultaneously, aiming at linking microbial activities under different environmental conditions to the POC export through the BP and RDOC production by the MCP, which would have an important implication in examining the $\mathrm{CO}_{2}$ outgassing scenarios in upwelling areas so as to better understand the mechanisms and variability of the marine carbon sink.

\section{Material and methods}

\subsection{Study sites}

In the study area of the western SCS, two well-developed cold-core cyclonic eddies (CE1 and CE2) were identified and documented by Acoustic Doppler current profiler (ADCP) data and negative sea-level anomaly during the GOE-2 cruise (on board RV Dongfanghong \#2, 14 August to 14 September 2007) (Zhang et al., 2009, 2011a; Hu et al., 2011). The satellite altimetric history (http://eddy. colorado.edu/ccar/data_viewer/index) suggested intensification of CE1 (decaying) and CE2 (young) during our sampling. Biogeochemical surveys (Fig. 1) were carried out to localize the eddies. For particle flux analysis, thirty-seven sites were sampled. Biological measurements and incubations were conducted at four representative sites: TS1, Y12, Y56 and SEATS. TS1 and Y12 were located in the center of CE1 and CE2, respectively, and the Y56 site at the CE1

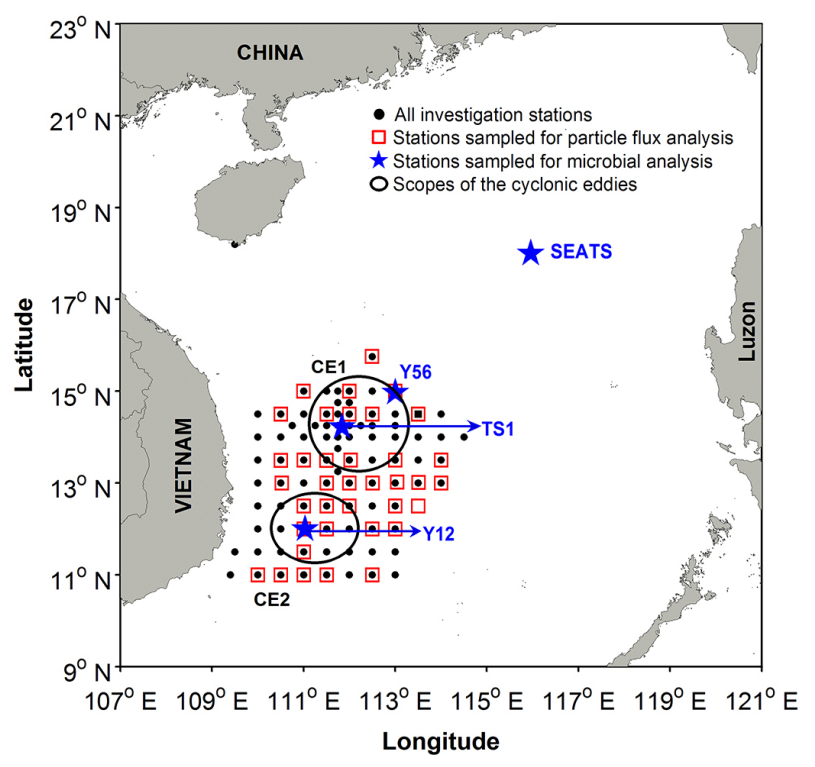

Fig. 1. Location of the study sites in the South China Sea. CE1: cold-core cyclonic eddy \#1; CE2: cold-core cyclonic eddy \#2. St. SEATS represents the Southeast Asia Time Series Station.

boundary. The SEATS site is the Southeast Asia Time Series Study station, which is an outside-eddy site monitoring background levels (Zhang et al., 2009) (Fig. 1).

\subsection{Biogeochemical parameters}

A SeaBird CTD-General Oceanic rosette sampler with GoFlo bottles (SBE 9/17 plus, SeaBird Inc., USA) was used to record temperature and salinity and to collect water samples. Samples for inorganic nutrients (nitrate + nitrite, phosphate, silicate) were filtered through $0.45 \mu \mathrm{m}$ cellulose acetate filters and measured immediately onboard using a flow injection analyzer (Tri-223 autoanalyzer) and standard spectrophotometric methods (Su-Cheng et al., 1990). Oxygen concentrations were determined on board using the Winkler method (Carpenter, 1965). Apparent oxygen utilization (AOU) and oxygen saturation $\left(\mathrm{O}_{2}^{S}\right)$ were estimated based on in situ $\mathrm{O}_{2}$, temperature and salinity (Garcia et al., 2006). The fluorescence of dissolved organic matter (FDOM) was measured on board using a Turner Designs (Model 10-AU, USA) fluorometer equipped with the FDOM optical kit at 310$390 \mathrm{~nm}$ excitation and at $400-600 \mathrm{~nm}$ emission after seawater was filtered through pre-cleaned $0.22 \mu \mathrm{m}$ pore size polycarbonate membrane filters (Millipore). The fluorescence of the samples is expressed in quinine sulfate units (QSU) where $1 \mathrm{QSU}$ is equivalent to the fluorescence of $1 \mu \mathrm{g} \mathrm{L}^{-1}$ quinine sulfate solution. 


\subsection{Phytoplankton analysis}

Samples for photosynthetic pigments analysis were collected on $0.7 \mu \mathrm{m}$ pore-size GF/F filters (Whatman). Photosynthetic pigments were extracted in N,N-dimethylformamide (Furuya et al., 1998) and analyzed using reverse phase HPLC on a C8 column and a modification of the method of Mantoura and Llewellyn (1983) and Van Heukelem et al. (2001), including peridinin, fucoxanthin, 19'-butfucoxanthin, 19'-hex-fucoxanthin, neoxanthin, prasinoxanthin, violaxanthin, alloxanthin, lutein, zeaxanthin, chlorophyll $b$, divinyl-chlorophyll $a$, and total chlorophyll $a$. Based on the pigment data, phytoplankton community composition was analyzed using CHEMTAX, including dinoflagellates, diatoms, haptophytes_4, haptophytes_3, chlorophytes, cryptophytes, Prochlorococcus, Synechococcus and prasinophytes (Mackey et al., 1996).

\section{$2.4{ }^{234} \mathrm{Th}$ analysis and particle flux estimation}

Total thorium-234 was determined using a small volume (2 or $4 \mathrm{~L}$ ) $\mathrm{MnO}_{2}$ co-precipitation method (Benitez-Nelson et al., 2001; Buesseler et al., 2001; Cai et al., 2006). Beta counting of ${ }^{234} \mathrm{Th}$ was carried out using a gas-flow proportional lowlevel beta counter (Model GM-25-5, RISØ National Laboratory, Denmark). Total ${ }^{234} \mathrm{Th}$ activity was calculated after recovery calibration and corrections from decay and ${ }^{234} \mathrm{Th}$ ingrowth from dissolved ${ }^{238} \mathrm{U}$ according to Cai et al. (2006). ${ }^{238} \mathrm{U}$ activity was calculated from the following equation:

${ }^{238} \mathrm{U}\left(\mathrm{dpmL}^{-1}\right)=0.07081 \times$ salinity (Chen et al., 1986).

Export flux of ${ }^{234} \mathrm{Th}$ was determined through ${ }^{234} \mathrm{Th} /{ }^{238} \mathrm{U}$ disequilibria under the assumptions of steady state and no physical horizontal transport. Particle organic carbon (POC) export flux was determined according to the ratio of POC to ${ }^{234}$ Th (Buesseler et al., 2006; Savoye et al., 2006), using the following equation:

POC flux $={ }^{234} \mathrm{Th}$ flux $\times\left(\mathrm{POC} /{ }^{234} \mathrm{Th}\right)($ Buesseler et al., 2006).

\subsection{Heterotrophic microbial abundance, production and respiration estimates}

Microbial abundance was determined by epifluorescence microscopy. Samples were stained with $4^{\prime}, 6^{\prime}$-diamidino-2phenylindole (DAPI) and counted under a Zeiss Axioplan 2 epifluorescence microscope. To determine heterotrophic microbial production, water samples were incubated with $\left[{ }^{3} \mathrm{H}\right]$ leucine $\left(10 \mathrm{nM}\right.$ final concentration; $65 \mathrm{Ci} \mathrm{mmol}^{-1}$, Amersham) at in situ temperature. The disintegrations per minute (DPM) were counted in a liquid scintillation counter and converted into leucine incorporation rates (Kirchman and Wheeler, 1998).

Microbial respiration rates were estimated indirectly. As the term "bacterial respiration (BR)" is more commonly used in research literature to refer to respiration by microbes, here we have designated $\mathrm{BR}$ to refer to microbial respiration. Likewise, the terms "bacterial growth rate (BG)", "bacterial growth efficiency (BGE)" are used correspondingly.

$\mathrm{BR}=(\mathrm{BG} \times \mathrm{ICF} \times \mathrm{CCF})(1 / \mathrm{BGE}-1)$

(Mourinõ-Carballido, 2009),

where BG can be obtained by the $\left[{ }^{3} \mathrm{H}\right]$-thymidine or $\left[{ }^{3} \mathrm{H}\right]-$ leucine technique; ICF and CCF are the isotope and carbon conversion factors; here, we used the ICF reported in Pacific by Kirchman (1992) $\left(0.108 \times 10^{18}\right.$ cells mol $^{-1}$ of incorporated leucine), the CCF of $20 \mathrm{fg} \mathrm{C}^{-1}{ }^{-1}$ (Lee and Fuhrman, $1987)$ and the BGE reported for open ocean regions (0.08; Robinson, 2008).

\section{$2.6 p \mathrm{CO}_{2}$ determination and air-sea $\mathrm{CO}_{2}$ flux estimation}

Surface water $x \mathrm{CO}_{2}$ (the mole fraction concentration of $\mathrm{CO}_{2}$ in the dried sample gas flow) was measured using a LI-COR 7000 nondispersive infrared spectrometer coupled to a gaswater equilibrator according to Zhai et al. (2005). The water temperature and salinity right before the equilibration chamber was recorded by $\mathrm{YSI}^{\circledR}$ temperature and salinity sensors. Meteorological data was obtained from the onboard weather station. The partial pressure of $\mathrm{CO}_{2}$ of the surface water at the temperature of equilibration [ $p \mathrm{CO}_{2}$ (eq), units: $\left.\mu \mathrm{atm}\right]$, the partial pressure of $\mathrm{CO}_{2}$ at the in situ temperature $\left[p \mathrm{CO}_{2}\right.$ (water), units: $\mu \mathrm{atm}]$, the partial pressure of $\mathrm{CO}_{2}$ in the air [ $p \mathrm{CO}_{2}$ (air), units: $\left.\mu \mathrm{atm}\right]$ and the air-sea $\mathrm{CO}_{2}$ flux were estimated according to Zhai et al. (2005). Temperature corrected $p \mathrm{CO}_{2}$ were estimated according to Takahashi et al. (1993). A positive value of air-sea $\mathrm{CO}_{2}$ flux indicates a transfer of $\mathrm{CO}_{2}$ from water to the atmosphere. Gas transfer velocity was calculated from wind speeds. The relationship of gas transfer velocity with wind speed proposed by Sweeney (2007) was used to estimate the value of air-sea $\mathrm{CO}_{2}$ flux.

\subsection{Statistical analysis}

Since normal distribution of the individual data sets was not met, we used the non-parametric Kruskal-Wallis test for comparison of variables between sites by SPSS software.

\section{Results and discussion}

\subsection{Upwelling of nutrient supply to the euphotic zone and biological responses}

The surface waters (upper $200 \mathrm{~m}$ ) of both CE1 and CE2 exhibited lower temperature, higher salinity, and higher nutrient levels as compared to the surrounding waters (Table 1; Fig. 2). Apparently, the cyclonic eddy isopycnal uplift resulted in shoaling of the mixed layer and nitracline at both 
Table 1. Hydrographic characteristics, phytoplankton, particle export parameters, bacterial abundance and respiration and air-sea $\mathrm{CO}_{2}$ flux in CE1, CE2 and surrounding waters. CE1: cyclonic eddy \#1; CE2: cyclonic eddy \#2. TChl $a$ : total chlorophyll $a$; SS: stable state; POC: particle organic carbon; BA: bacterial abundance; BR: bacterial respiration rate. Non-parametric Kruskal-Wallis test was used for comparison of variables between sites.

\begin{tabular}{|c|c|c|c|}
\hline Parameters & CE1 & CE2 & Reference site \\
\hline \multicolumn{4}{|l|}{ Hydrography } \\
\hline Depth of mixed layer $(\mathrm{m})$ & $\sim 25^{\mathrm{a}}$ & $\sim 15^{\mathrm{b}}$ & $\sim 40^{\mathrm{c}}$ \\
\hline Euphotic depth ( $1 \%$ light level, $\mathrm{m})$ & $\sim 62^{\mathrm{a}}$ & $\sim 63^{\mathrm{b}}$ & $\sim 78^{\mathrm{c}}$ \\
\hline Nitracline depth (m) & $\sim 20^{\mathrm{a}}$ & $\sim 10^{\mathrm{b}}$ & $\sim 70^{\mathrm{c}}$ \\
\hline Temperature $\left({ }^{\circ} \mathrm{C}\right.$, at $\left.25 \mathrm{~m}\right)$ & $27.72^{\mathrm{a}}$ & $23.33^{\mathrm{b}}$ & $29.63^{c}$ \\
\hline Salinity (at $25 \mathrm{~m}$ ) & $34.12^{\mathrm{a}}$ & $34.08^{\mathrm{b}}$ & $33.99^{\mathrm{c}}$ \\
\hline $\mathrm{AOU}\left(\mathrm{mol} \mathrm{m}^{-2}, 50-100 \mathrm{~m}\right)$ & $4.83^{\mathrm{a}}$ & $5.89^{\mathrm{b}}$ & $2.31^{\mathrm{c}}$ \\
\hline \multicolumn{4}{|l|}{ Phytoplanktond $^{\mathrm{d}}$} \\
\hline TChl $a\left(\mathrm{mg} \mathrm{m}^{-2}, 0-50 \mathrm{~m}\right)^{* *}$ & $12.3 \pm 3.68(\mathrm{~N}=23)$ & $13.8 \pm 4.91(\mathrm{~N}=11)$ & $10.1 \pm 7.89(\mathrm{~N}=47)$ \\
\hline Fucoxanthin $\left(\mathrm{mg} \mathrm{m}^{-2}, 0-50 \mathrm{~m}\right)$ & $0.60 \pm 0.26(\mathrm{~N}=22)$ & $1.14 \pm 1.10(\mathrm{~N}=11)$ & $1.07 \pm 1.89(\mathrm{~N}=47)$ \\
\hline Divinyl chorophyll $a\left(\mathrm{mg} \mathrm{m}^{-2}, 0-50 \mathrm{~m}\right)^{* *}$ & $2.88 \pm 1.13(\mathrm{~N}=22)$ & $1.97 \pm 2.02(\mathrm{~N}=11)$ & $1.72 \pm 0.90(\mathrm{~N}=47)$ \\
\hline \multicolumn{4}{|l|}{ Particle export $^{d}$} \\
\hline SS ${ }^{234} \mathrm{Th}$ flux @ $100 \mathrm{~m}\left(\mathrm{dpm} \mathrm{m}^{-2} \mathrm{~d}^{-1}\right)^{*}$ & $712 \pm 521(\mathrm{~N}=8)$ & $1609 \pm 572(\mathrm{~N}=6)$ & $1279 \pm 697(\mathrm{~N}=22)$ \\
\hline $\operatorname{POC}\left(\times 10^{2} \mathrm{~mol} \mathrm{C} \mathrm{m}^{-2}, 0-100 \mathrm{~m}\right)^{*}$ & $1.76 \pm 0.26(\mathrm{~N}=8)$ & $2.18 \pm 0.38(\mathrm{~N}=6)$ & $1.78 \pm 0.35(\mathrm{~N}=17)$ \\
\hline $\mathrm{POC} / 234 \mathrm{Th} @ 100 \mathrm{~m}(\mu \mathrm{mol} \mathrm{Cdpm}-1)$ & $3.43 \pm 1.00(=8)$ & $3.66 \pm 1.00(=6)$ & $3.66 \pm 1.12(\mathrm{~N}=22)$ \\
\hline 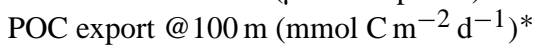 & $2.50 \pm 2.03(\mathrm{~N}=8)$ & $6.16 \pm 3.74(\mathrm{~N}=6)$ & $4.92 \pm 3.63(\mathrm{~N}=22)$ \\
\hline \multicolumn{4}{|l|}{ Bacteria } \\
\hline $\mathrm{BA}\left(10^{5}\right.$ cells $\left.\mathrm{mL}^{-1}\right)$ & $2.41^{\mathrm{d}}(\mathrm{N}=2)$ & $1.73^{\mathrm{b}}$ & $2.14^{\mathrm{c}}$ \\
\hline $\mathrm{BR}\left(\mathrm{mg} \mathrm{Cm} \mathrm{m}^{-2} \mathrm{~d}^{-1}, 0-100 \mathrm{~m}\right)$ & $327^{\mathrm{d}}(\mathrm{N}=2)$ & $255^{\mathrm{b}}$ & $292^{c}$ \\
\hline \multicolumn{4}{|l|}{ Air-sea $\mathrm{CO}_{2}$ flux ${ }^{\mathrm{d}}$} \\
\hline Observed $p \mathrm{CO}_{2}(\mu \mathrm{atm})$ & $417 \pm 11(\mathrm{~N}=9112)$ & $408 \pm 7(\mathrm{~N}=1330)$ & $400 \pm 8(\mathrm{~N}=13754)$ \\
\hline Temperature corrected $p \mathrm{CO}_{2}(\mu \mathrm{atm})^{\mathrm{e}}$ & $426 \pm 16(\mathrm{~N}=9112)$ & $405 \pm 12(\mathrm{~N}=1330)$ & $396 \pm 18(\mathrm{~N}=13754)$ \\
\hline $\mathrm{CO}_{2}$ flux $\left(\mathrm{mmol} \mathrm{m}^{-2} \mathrm{~d}^{-1}\right)^{* *}$ & $4.15 \pm 0.84(\mathrm{~N}=9112)$ & $3.43 \pm 0.59(\mathrm{~N}=1330)$ & $2.82 \pm 0.65(\mathrm{~N}=13754)$ \\
\hline
\end{tabular}

${ }^{\mathrm{a}}$ Data from the CE1 center site TS $1{ }^{\mathrm{b}}$ Data from the CE2 center site Y12; ${ }^{\mathrm{c}}$ Data from the reference site SEATS; ${ }^{\mathrm{d}}$ Data were mean $\pm \mathrm{SD}$ (standard deviation) from the CE1 and CE2 regions and the reference sites of surrounding waters; ${ }^{\mathrm{e}}$ Normalized to the arithmetical average of underway SST $\left(28.716^{\circ} \mathrm{C}\right) ;{ }^{* *} P<0.01$; $* P<0.05$.

cases (Table 1; Fig. 2). Consequently, the nutrients injected into the nutrient-depleted euphotic zone effectively stimulated phytoplankton growth as indicated by the increase of chlorophyll a concentration (Table 1, Fig. 3a). The total chlorophyll $a$ maximum values at the eddy central sites of CE1 (TS1) and CE2 (Y12) were 0.65 and $0.75 \mu \mathrm{g} \mathrm{L}-1$, respectively, while only 0.46 and $0.35 \mu \mathrm{g} \mathrm{L}^{-1}$ at the CE1 periphery site Y56 and the reference site SEATS, respectively. Interestingly, while nitrogen and phosphorus were depleted in the surface $50 \mathrm{~m}$ at both CE1 and CE2, silicate at CE1 seemed to be in relative abundance compared to CE2 (Fig. 2). Photosynthetic pigments analysis indicated that the dominant autotrophs at CE1 were cyanobacteria rather than diatoms as occurred at CE2 (Table 1, Fig. 3b and c), suggesting that diatoms in CE1 were surpassed by cyanobacteria and not well developed, allowing extra silicate to be left over in the environment. Alternatively, a diatom bloom had decayed, and silicate was present from dissolution. Therefore, the less intense upwelling (e.g., during the later intensification period) and consequently higher temperature (which favors cyanobacteria) at CE1 than CE2 could be responsible for the corresponding differences between their community structures. CE2 upwelling brought nutrients to the upper layer of the euphotic zone where light was replete as indicated by the mixed layer, eutrophic depth, and nitracline depth (Table 1), and diatoms responded and bloomed; nutrients translocated by CE1 upwelling can reach only the lower layer of the euphotic zone, where picoplankton are dominant; however, diatoms did not respond as strongly due to lack of sunlight at that depth. A clear pattern in the depth profiles of phytoplankton pigments was observed: the maximum chlorophyll $a$ depth (MCD) was the shallowest in the strongest upwelling area (CE2) where diatoms were dominant, but deeper in weak- or non-upwelling areas where Prochlorococcus were prevalent (Fig. 3a). As a result of biological interactions under upwelling conditions, heterotrophic microbes in 

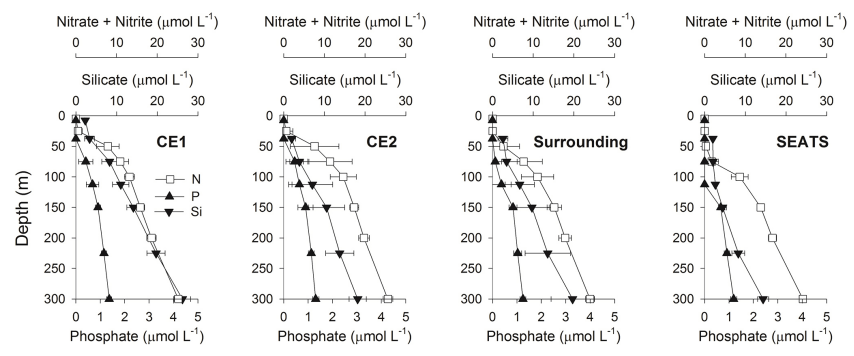

Fig. 2. Depth profiles of nutrient concentration averaged over respective stations inside and outside the eddies and the reference site (St. SEATS). Value " 0 " means below the detection limit of the standard spectrophotometric methods. Error bars indicate standard deviations.
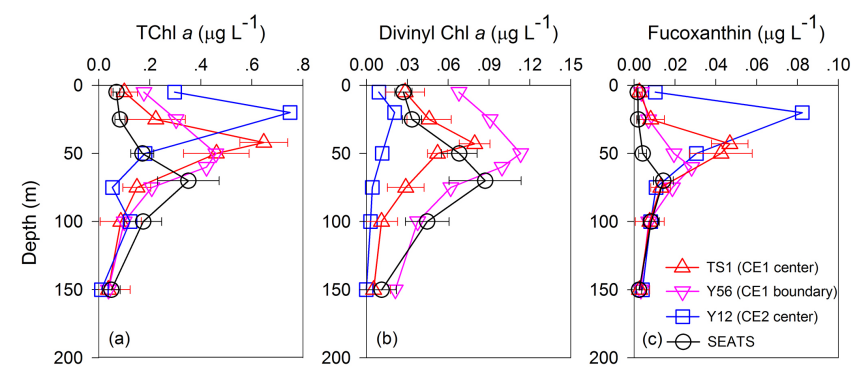

Fig. 3. Depth profiles of phytoplankton pigments at the eddy centers (TS1 and Y12), the eddy edge (Y56) and the reference site (St. SEATS). Data are the average values over time series analysis at St. TS1 $(\mathrm{N}=6)$ and SEATS $(\mathrm{N}=7)$. Error bars indicate standard deviations. TChl $a$ : total chlorophyll $a$.

the middle euphotic zone $(50 \mathrm{~m})$ occurred at varying levels of abundance among the upwelling sites (CE1 boundary $>$ CE1 center $>$ CE2 center) (Table 1) similar to Prochlorococcus (Fig. 3b), rather than to diatoms (Fig. 3c) (also see Sect. 3.3).

\subsection{Responses of POC export flux}

Total ${ }^{234} \mathrm{Th}$ activities varied with depth ranging from $0.42 \pm 0.06 \mathrm{dpm} \mathrm{L}^{-1}$ at $2 \mathrm{~m}$ to $2.78 \pm 0.08 \mathrm{dpm} \mathrm{L}^{-1}$ at $100 \mathrm{~m}$ in the entire study area. The mean values of ${ }^{234} \mathrm{Th}$ activities at $100 \mathrm{~m}$ of CE1, CE2, and surrounding non-eddy sites were $2.45,2.41$ and $2.32 \mathrm{dpm} \mathrm{L}^{-1}$, respectively (Fig. 4). The largest disequilibrium between ${ }^{234} \mathrm{Th}$ and its parent ${ }^{238} \mathrm{U}$ occurred at the upper euphotic zone of CE2, indicating it as the site of highest particle export. In contrast, the smallest export signals were observed in CE1 (Fig. 4). The POC fluxes at $100 \mathrm{~m}$ estimated through the ${ }^{234} \mathrm{Th}$ activity showed a similar pattern in that the highest and lowest POC fluxes occurred in CE2 $\left(6.16 \pm 3.74 \mathrm{mmol} \mathrm{C} \mathrm{m}^{-2} \mathrm{~d}^{-1}\right)$ and CE1 $(2.50 \pm 2.03$ $\left(\mathrm{mmol} \mathrm{C} \mathrm{m}{ }^{-2} \mathrm{~d}^{-1}\right)$, respectively. Independent samples $t$ test $(p<0.05)$ analysis suggests that the difference in POC flux between CE1 and CE2 is significant (Table 1). Such difference is consistent with the difference in phytoplankton com-

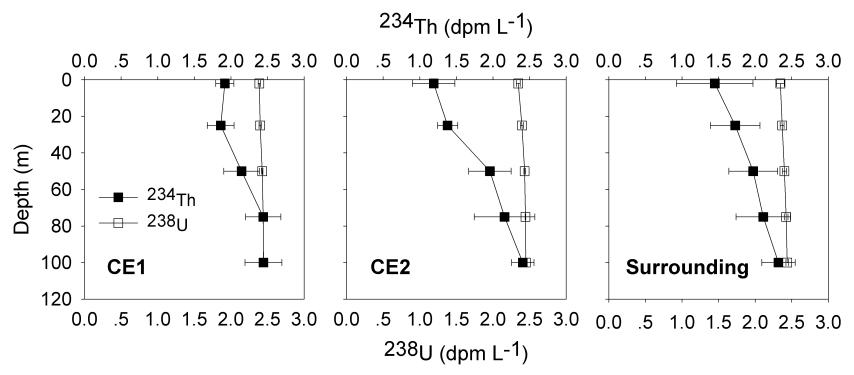

Fig. 4. Depth profiles of ${ }^{234} \mathrm{Th}$ and ${ }^{238} \mathrm{U}$ activities averaged over respective stations inside and outside the eddies. Error bars indicate standard deviations.

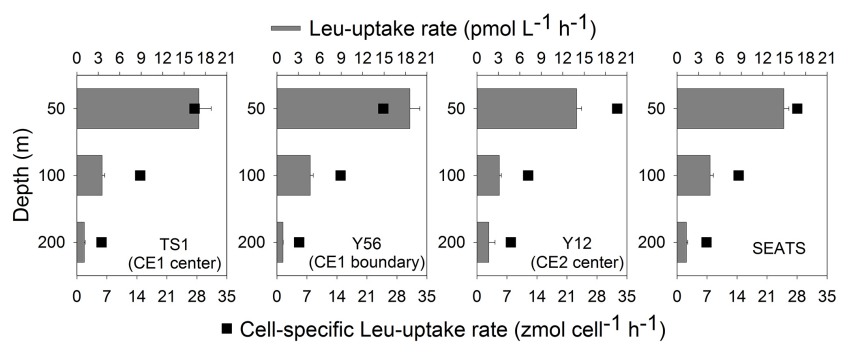

Fig. 5. Bulk leucine incorporation rates and cell-specific leucine incorporation rates at representative depths in the eddy centers (TS1 and Y12), the eddy edge (Y56) and the reference site (St. SEATS).

munity structure in that diatoms contribute more to POC export fluxes at CE2 than at CE1.

\subsection{Microbial respiration contributing to attenuation of POC export and $\mathrm{CO}_{2}$ outgassing}

In order to test whether microbial activity significantly influenced POC export flux in the two eddy-induced upwelling ecosystems, microbial abundance and activity were investigated at two representative stations of CE1, one station of CE2, as well as at St. SEATS (Fig. 1). Generally, microbial abundance decreased dramatically with depth, but showed distinct differences between the four sites. At $50 \mathrm{~m}$ where upwelling impacts were significant, the highest abundance was observed in CE1, while the lowest abundance occurred in the center of CE2 (Table 1). Leucine uptake, as a measure of microbial activity, decreased with depth by two orders of magnitude within $200 \mathrm{~m}$ (Fig. 5). As with abundance, microbial activities at $50 \mathrm{~m}$ depth were also higher at the two stations in CE1 (17.08 and $18.62 \mathrm{pmol} \mathrm{L}^{-1} \mathrm{~h}^{-1}$ at sites TS1 and Y56, respectively) than that in the center of CE2 (13.95 pmol L ${ }^{-1} \mathrm{~h}^{-1}$ at site Y12). However, when abundance-specific (unicellular) leucine uptake rate is considered, the highest value was observed at the center of CE2 (Fig. 5). CE2 has been characterized as being more intense, as the ADCP data documented counterclockwise currents of higher speed in CE2 $\left(1.1 \mathrm{~m} \mathrm{~s}^{-1}\right.$ at maximum) than in CE1 $\left(0.7 \mathrm{~m} \mathrm{~s}^{-1}\right)$ (Zhang et al., 2011b), and the age of CE2 was 
younger than CE1 as seen from the satellite altimetric history. Thus, the microbial abundance in the shallow water of CE2 was likely diluted by deep water with low microbial abundance; however, cell activity could be stimulated by labile organic carbon which was released from enhanced phytoplankton biomass. In CE1, POC export flux was lowest whereas $\mathrm{BR}$ was highest, corresponding to the highest temperature corrected $p \mathrm{CO}_{2}(426 \pm 16 \mu \mathrm{atm})$ and air-sea $\mathrm{CO}_{2}$ flux $\left(4.15 \pm 0.84 \mathrm{mmol} \mathrm{m}^{-2} \mathrm{~d}^{-1}\right)$ among all the investigation sites. This observation cannot be attributed to DIC release, as CE2 rather than CE1 exhibited the strongest upwelling and thus the strongest DIC release from sub-thermocline water as indicated by the mixed layer and nitracline depths (Table 1); however, the temperature corrected $p \mathrm{CO}_{2}(405 \pm 12 \mu \mathrm{atm})$ and total $\mathrm{CO}_{2}$ outgassing $\left(3.43 \pm 0.59 \mathrm{mmol} \mathrm{m}^{-2} \mathrm{~d}^{-1}\right)$ in CE2 was found to be lower than CE1. That is, it was microbial activity which did matter for the $\mathrm{CO}_{2}$ outgassing in this upwelling area. In fact, in CE1, the average carbon loss by microbial respiration was about eleven-fold the average POC export flux at $100 \mathrm{~m}$ (Table 1). The enhanced total microbial activity could have consumed more organic carbon leading to lower POC export flux and higher $\mathrm{CO}_{2}$ outgassing in CE1 than the other sites (Table 1). The satellite altimetric and chlorophyll data series (http://gdata1.sci.gsfc.nasa.gov/ daac-bin/G3/batchDownload.cgi) suggested that the primary production at the initial stages of CE1 could be slightly lower than that of CE2, but this difference was not profound enough to cause the large difference in POC export between CE1 and CE2. It is most likely that upwelling induced nutrient input enhanced phytoplankton biomass and labile organic carbon release which then stimulated bacterial growth and respiration. Bacteria became more competent in attaching to and consuming POC and attenuating POC export flux. As for the case of CE2, a diatom-dominated community (Table 1), whose growth was induced by the nutrient supply, would be the main reason for the high POC export flux. Taken together, the intensity and age of the two eddies and the different responses in phytoplankton community and microbial activity suggest that phytoplankton rapidly responded to upwelled nutrients, accumulating biomass and causing high POC export at the initial intensification period (such as the case of the of CE2); bacteria were subsequently stimulated by nutrients and labile DOC produced by phytoplankton resulting in high respiration rates during the later intensification period (such as the case of of CE1).

It has also been reported that centers of cyclonic eddies in the northwestern subtropical Atlantic (Mouriño-Carballido, 2009) were associated with low net community production as the result of a noticeable increase in BR, although several observations have reported reduction in respiration rates in cyclonic eddies in the northeastern subtropical Atlantic (Gonzalez et al., 2001; Maixandeau et al., 2005). This was attributed to lower microbial abundance or lower maintenance respiration of heterotrophic microbes inside rather than outside the cyclonic eddy (Gonzalez et al., 2001). Although low

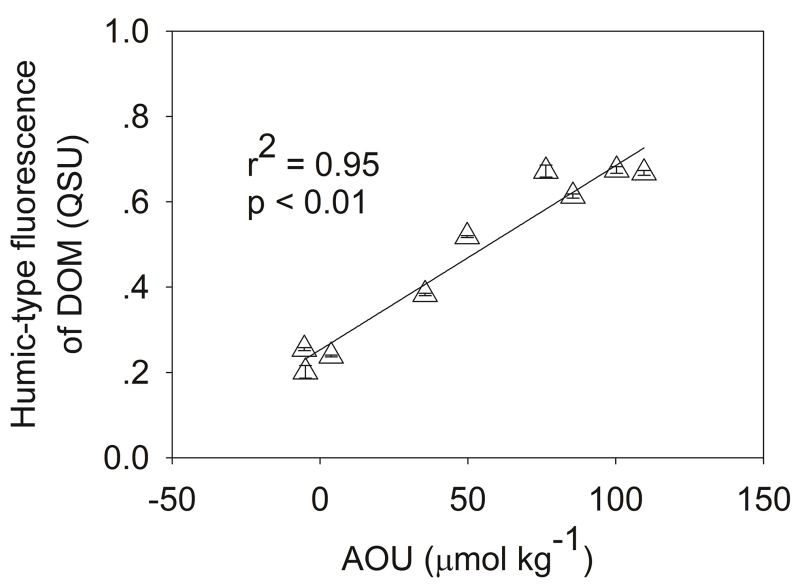

Fig. 6. Relationships between humic-type fluorescent dissolved organic matter (FDOM) and apparent oxygen utilization (AOU) in the euphotic zone of CE1. Error bars indicate standard deviations.

BR could occur at certain upwelling stages as was observed in this study in CE2, which was due to the low bacterial abundance diluted by deep water, gradually increasing BR was identified as the prevailing feature of the cyclonic eddies (Table 2).

\subsection{Microbial oxygen consumption and organic carbon transformation}

AOU has been demonstrated as a useful indicator of microbial consumption of oxygen in the water column (Hayase and Shinozuka, 1995; Yamashita and Tanoue, 2008). In our study, data taken from both CE1 and CE2 yielded higher AOU values than the reference site (Table 1). The effects of oxygen consumption are also verified by the microbial metabolic output - the fluorescence of humic-type dissolved organic matter, which was measured as an indicator of RDOC (Yamashita and Tanoue, 2008). Our earlier studies have shown that humic-type FDOM and the ratio of humic-like FDOM to bulk DOC concentrations were generally higher in the cyclonic eddy centers than at the reference site St. SEATS, especially at 35 to $75 \mathrm{~m}$ depths (Zhang et al., 2009). In our study, humic-type FDOM in the euphotic zone also displayed higher fluorescence intensity in the upwelling areas than the reference site. Furthermore, a significant positive correlation $(p<0.01)$ between AOU and FDOM was observed in the euphotic zone of CE1 where microbial respiration was strong (Fig. 6), suggesting that FDOM was associated with microbial decomposition of organic matter and the consumption of oxygen.

\subsection{Influence of upwelling on $\mathrm{CO}_{2}$ outgassing and carbon sequestration}

Our results suggest that when nutrient-rich deep water with low abundance of microbes is upwelled to the upper euphotic 
Table 2. Bacterial respiration inside and outside the mesoscale features in the Atlantic.

\begin{tabular}{|c|c|c|c|}
\hline Study area & Study site & $\begin{array}{l}\mathrm{BR}^{\mathrm{a}} \\
\left(\mathrm{mg} \mathrm{C} \mathrm{m}{ }^{-3} \mathrm{~d}^{-1}\right. \\
0-100 \mathrm{~m})\end{array}$ & Reference \\
\hline \multicolumn{4}{|c|}{ Northeastern Atlantic } \\
\hline & Ambient Stn 159 & 54.16 & Lochte et al. (1987) \\
\hline & Eddy centre Stn161 & 31.75 & \\
\hline & Eddy centre Stn 162 & 32.04 & \\
\hline & Eddy margin Stn163 & 37.18 & \\
\hline & Ambient Stn164 & 16.23 & \\
\hline & Reference station Stn 170 & 3.35 & \\
\hline \multicolumn{4}{|c|}{ Northwestern Sargasso Sea } \\
\hline & Eddy 1 edge $(\mathrm{N}=10)$ & 2.05 & Ewart et al. (2008) \\
\hline & Eddy 1 center $(\mathrm{N}=3)$ & 1.68 & \\
\hline & Eddy 2 edge $(\mathrm{N}=3)$ & 2.31 & \\
\hline & Eddy 2 center $(\mathrm{N}=1)$ & 1.85 & \\
\hline \multicolumn{4}{|l|}{ BATS } \\
\hline & Cyclonic eddies B178 & 7.39 & \\
\hline & Reference data ${ }^{b}$ & 3.08 & \\
\hline \multicolumn{4}{|c|}{ Sargasso Sea } \\
\hline & Cyclones & 0.20 & Mourinõ-Carballido (2009) \\
\hline \multicolumn{4}{|l|}{ BATS } \\
\hline & Cyclones center & 1.09 & \\
\hline & Cyclones edge & 0.01 & \\
\hline & Anticyclone & 0.64 & \\
\hline & $\mathrm{CA}^{\mathrm{c}}$ & -0.55 & \\
\hline \multicolumn{4}{|c|}{$\begin{array}{l}\text { The Canary Islands } \\
\left(15-19^{\circ} \mathrm{W}, 27-29^{\circ} \mathrm{N}\right)\end{array}$} \\
\hline & Cyclone1 & 18.72 & Baltar et al. (2010) \\
\hline & Far-fields (FF) 1 & 24.44 & \\
\hline & Cyclone2 & 12.63 & \\
\hline & Far-fields (FF)2 & 3.62 & \\
\hline
\end{tabular}

zone, a corresponding bloom in phytoplankton, such as diatoms, would occur; meanwhile, an initial reduction in total microbial respiration would also occur. These two events would consequently result in an increase of POC export flux, as demonstrated in the case of CE2. In the case that diatom blooms do not occur or picoplankton populations dominate the community, as with the case of CE1, the microbial loop develops, and microbial respiration is mobilized. This exacerbates the attenuation of POC flux and could play a critical role for a marine upwelling area to be an outgassing area of $\mathrm{CO}_{2}$.

Taken together, POC sinking and microbial respiration suggested that the remineralization depth, a comprehensive parameter, can be referred to. A three-dimensional global ocean biogeochemistry model has shown that a modest change in remineralization depth can have a substantial impact on atmospheric $\mathrm{CO}_{2}$ concentrations (Kwon et al., 2009). As upwelling processes influence nutrients, temperature, oxygen concentration, as well as stratification and com- munity composition, all these variables influence the depth of remineralization (Kwon et al., 2009). Therefore, upwelling scenario models should be established to better illustrate the effects of upwelling on ocean carbon uptake/outgassing dynamics.

Based on the above consideration, two scenario models can be established (Fig. 7). When an upwelling event brings nutrients and DIC to the upper layer of the euphotic zone where light is replete, diatoms respond and bloom and consequently enhance POC export and excess $\mathrm{CO}_{2}$ outgassing (Burt et al., 2013; Dai et al., 2013); Meanwhile, total microbial respiration would be decreased due to low abundance and low temperature brought by the deep water. As a result, POC export flux exceeds respiration flux, and even could exceed total $\mathrm{CO}_{2}$ flux (Fig. 7a; instance: CE2). This would deepen the mineralization depth and thus favor $\mathrm{CO}_{2}$ uptake by the ocean (Kwon et al., 2009). If the upwelled nutrients and DIC can reach only the lower layer of the euphotic zone where picoplankton, especially Prochlorococcus, are 


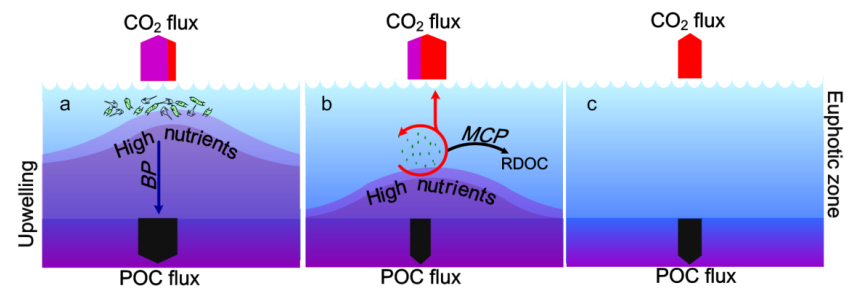

Fig. 7. Scenario models for the effects of upwelling on ocean carbon uptake/outgassing dynamics. Note the scenarios assume steady state of a water body without advective exchanges at horizontal dimensions. Red arrows indicate respiration flux; pink arrows indicate DIC release from deep water. (a) Scenario of POC export flux exceeding total $\mathrm{CO}_{2}$ flux: nutrients are injected into the upper layer of the euphotic zone; diatoms are dominant; POC export exceeds $\mathrm{CO}_{2}$ outgassing; the biological pump is the prevailing mechanism for carbon sequestration. (b) Scenario of total $\mathrm{CO}_{2}$ flux exceeding POC export flux: nutrients are injected only into the lower layer of the euphotic zone; Prochlorococcus are dominant; microbial respiration is mobilized; $\mathrm{CO}_{2}$ outgassing exceeds $\mathrm{POC}$ export; the $\mathrm{MCP}$ is the prevailing mechanism for carbon sequestration. (c) A nonupwelling scenario for reference.

dominant, diatoms do not respond much to the upwelling due to lack of light exposure at that depth; instead, the microbial loop could be very active (Hagström et al., 1988; Azam et al., 1993). As a result, microbial respiration flux and total $\mathrm{CO}_{2}$ flux would exceed POC export flux (Fig. 7b; instance: CE1). This would result in shoaling the mineralization depth and result in a decrease in oceanic DIC capacity (Kwon et al., 2009).

In addition, the common notion that "outgassing areas are carbon sources" needs to be revised for the case of marine upwelling regions. As shown in Fig. 8, for a steady upwelling system, $\mathrm{CO}_{2}$ released from DIC-rich deep water $\left(\mathrm{DIC}_{\mathrm{up}}\right)$ has to be taken into consideration in the equilibrium of carbon sources/sinks. Even if $\mathrm{CO}_{2}$ dissolving into the sea from atmosphere $\left(\mathrm{CO}_{2 \text { in }}\right)<\left(\mathrm{CO}_{2}\right.$ from respiration $\left.\left(\mathrm{CO}_{2 \text { res }}\right)+\mathrm{DIC}_{\mathrm{up}}\right)$, it does not necessarily preclude a state of massive carbon sequestration in the system, and sequestered carbon need not be exported out entirely as POC ( $\left.\mathrm{POC}_{\exp }\right)$. It can be stored in dissolved form as RDOC through the MCP approach (Jiao et al., 2010). Therefore, as long as the condition $\left(\mathrm{CO}_{2 \text { in }}+\mathrm{POC}_{\text {exp }}+\mathrm{RDOC}\right)>\left(\mathrm{CO}_{2 \text { res }}+\mathrm{DIC}_{\mathrm{up}}\right)$ is met, the equilibrium will favor carbon sequestration, even if it is outgassing. Upwelling areas can be $\mathrm{CO}_{2}$ outgassing and yet export POC through $\mathrm{BP}$ and produce RDOC through MCP. Therefore, the adjudgment of a marine region to be a carbon sink or source should be made carefully and in consideration of the long-term balance between the amount of outgassing carbon and the sum of the outputs of the BP and the MCP, rather than simply according to momentary $\mathrm{CO}_{2}$ partial pressures.

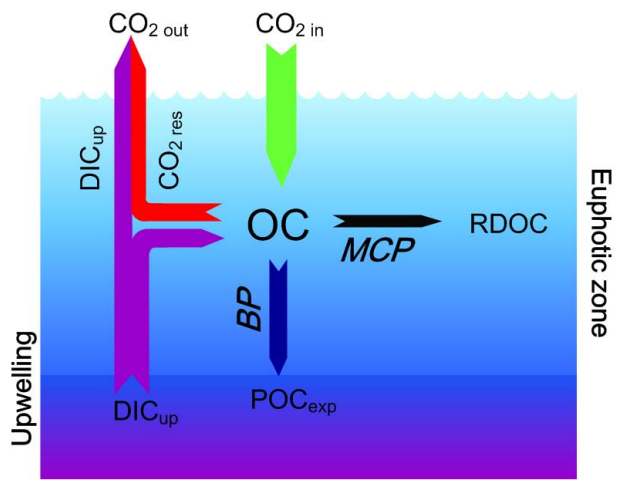

Fig. 8. A diagram showing the factors influencing $\mathrm{CO}_{2}$ dynamics in an upwelling area. $\mathrm{CO}_{2}$ in $: \mathrm{CO}_{2}$ dissolving into the sea from atmosphere; $\mathrm{CO}_{2 \text { out }}: \mathrm{CO}_{2}$ released from the ocean; OC: organic carbon; RDOC: refractory dissolved organic carbon which could stay in the water column for long-term storage; $\mathrm{POC}_{\mathrm{exp}}$ : particulate organic carbon exported out of the euphotic zone; $\mathrm{DIC}_{\mathrm{up}}$ : dissolved inorganic carbon in the upwelled water, which can be further released into the atmosphere when conditions permit; $\mathrm{CO}_{2}$ res $: \mathrm{CO}_{2}$ from respiration. See the text for further details. It is also shown that carbon sequestration takes place through the $\mathrm{BP}$ and $\mathrm{MCP}$ in an upwelling area even if it is outgassing.

\section{Summary}

The results from the present study indicate that when nutrient-rich deep water with low abundance of prokaryotes is upwelled to the upper ocean, a corresponding rapid growth of phytoplankton and an initial reduction in total bacterial respiration might result in an increase of POC export flux, as demonstrated in the case of CE2, whose age was younger and whose upwelling was stronger than that of CE1. In the case that phytoplankton blooming does not occur or picophytoplankton dominates the community, as in the case of CE1 during the later intensification period, the injected nutrients and phytoplankton originated labile organic carbon could stimulate microbial respiration, which exacerbates the attenuation of POC flux.

The results further suggest that while upwelling usually enhances primary production through the injection of nutrients into the euphotic zone, upwelled DIC-rich deep water could release $\mathrm{CO}_{2}$ and ultimately result in outgassing. Moreover, microbial respiration could be stimulated and accelerated by this nutrient enhancement and subsequent phytoplankton labile DOC, and thus result in a productive upwelling area to be $\mathrm{CO}_{2}$ outgassing area. In terms of carbon sequestration, upwelling usually strengthens the POC-based BP; however, if picoplankton (e.g., Prochlorococcus) rather than net phytoplankton (e.g., diatoms) dominate the system, their non-sinking POC favors the microbial loop rather than the BP. The remineralization depth would vary with the interaction between BP flux and respiration rate, and influence the DIC capacity in the upper ocean. Nevertheless, even if the 
$\mathrm{BP}$ is severely weakened, RDOC formation by the MCP can still work well, and carbon sequestration takes place while an upwelling area is outgassing. Given the tremendous complexity of the biological and biogeochemical responses to upwelling events, further high-frequency sampling and simultaneous observations of the BP and the MCP in the field are essential for a better understanding of carbon sequestration in the ocean.

Acknowledgements. We would like to acknowledge the financial support granted by the MOST 973 program 2013CB955700, the NSFC projects 91028001, 41121091, 41176095 and 41023007, and the SOA project GASI-03-01-02-05. We thank the captain and crew of the RV Dongfanghong \#2 and our colleagues who participated in the GOE-2 cruise.

Edited by: H. Thomas

\section{References}

Archer, D.: Upper ocean physics as relevant to ecosystem dynamics: a tutorial, Ecol. Appl., 5, 724-739, 1995.

Azam, F., Fenchel, T., Field, J. G., Gray, J. S., Meyer-Reil, L. A., and Thingstad, F.: The ecological role of water-column microbes in the sea, Mar. Ecol. Prog. Ser., 10, 257-263, 1983.

Azam, F., Smith, D. C., Steward, G. F., and Hagström, Å.: Bacteriaorganic matter coupling and its significance for oceanic carbon cycling, Microb. Ecol., 28, 167-179, 1993.

Beaulieu, S. E.: Accumulation and fate of phytodetritus on the sea floor, Oceanogr. Mar. Biol. Annu. Rev., 40, 171-232, 2002.

Benitez-Nelson, C. R., Buesseler, K. O., Van der Loeff, M. R., Andrews, J., Ball, L., Crossin, G., and Charette, M.: Testing a new small-volume technique for determining ${ }^{234} \mathrm{Th}$ in seawater, J. Radioan. Nucl. Ch., 248, 795-799, 2001.

Benitez-Nelson, C. R., Bidigare, R. R., Dickey, T. D., Landry, M. R., Leonard, C. L., Brown, S. L., Nencioli, F., Rii, Y. M., Maiti, K., Becker, J. W., Bibby, T. S., Black, W., Cai, W. J., Carlson, C. A., Chen, F., Kuwahara, V. S., Mahaffey, C., McAndrew, P. M., Quay, P. D., Rappe, M. S., Selph, K. E., Simmons, M. P., and Yang, E. J.: Mesoscale eddies drive increased silica export in the subtropical Pacific Ocean, Science, 316, 1017-1021, 2007.

Benner, R. and Herndl, G. J.: Bacterially derived dissolved organic matter in the microbial carbon pump, in: Microbial Carbon Pump in the Ocean, edited by: Jiao, N., Azam, F., and Sanders, S., Science/AAAS, Washington, DC, Science/AAAS, 46-48, 2011.

Boyd, P. and Newton, P.: Does planktonic community structure determine downward particulate organic carbon flux in different oceanic provinces?, Deep-Sea Res. I., 46, 63-91, 1999.

Buesseler, K. O., Ball, L., Andrews, J., Cochran, J. K., Hirschberg, D. J., Bacon, M. P., Fleer, A., and Brzezinski, M.: Upper ocean export of particulate organic carbon and biogenic silica in the Southern Ocean along $170^{\circ} \mathrm{W}$, Deep-Sea Res. II., 48, 42754297, 2001.

Buesseler, K. O., Benitez-Nelson, C. R., Moran, S. B., Burd, A., Charette, M., Cochran, J. K., Coppola, L., Fisher, N. S., Fowler, S. W., and Gardner, W. D.: An assessment of particulate organic carbon to thorium-234 ratios in the ocean and their impact on the application of ${ }^{234} \mathrm{Th}$ as a POC flux proxy, Mar. Chem., 100, 213-233, 2006.
Burt, W. J., Thomas, H., and Auclair, J.-P.: Short-lived radium isotopes on the Scotian Shelf: Unique distribution and tracers of cross-shelf $\mathrm{CO}_{2}$ and nutrient transport, Mar. Chem., 156, 120129, 2013.

Cai, P., Dai, M., Lv, D., and Chen, W.: An improvement in the smallvolume technique for determining thorium-234 in seawater, Mar. Chem., 100, 282-288, 2006.

Carpenter, J. H.: The Chesapeake Bay Institute technique for the Winkler dissolved oxygen method, Limnol. Oceanogr., 10, 141143, 1965.

Chen, F., Cai, W. J., Benitez-Nelson, C., and Wang, Y.: Sea surface $p \mathrm{CO}_{2}$-SST relationships across a cold-core cyclonic eddy: Implications for understanding regional variability and air-sea gas exchange, Geophys. Res. Lett., 34, L10603, doi:10.1029/2006GL028058, 2007.

Chen, J. H., Lawrence Edwards, R., and Wasserburg, G. J.: ${ }^{238} \mathrm{U}$, ${ }^{234} \mathrm{U}$ and ${ }^{232} \mathrm{Th}$ in seawater, Earth. Planet. Sc. Lett., 80, 241251, 1986.

Dai, M., Cao, Z., Guo, X., Zhai, W., Liu, Z., Yin, Z., Xu, Y., Gan, J., Hu, J., and Du, C.: Why are some marginal seas sources of atmospheric $\mathrm{CO}_{2}$ ?, Geophys. Res. Lett., 40, 2154-2158, 2013.

Furuya, K., Hayashi, M., and Yabushita, Y.: HPLC determination of phytoplankton pigments using N, N-dimethylformamide, J. Oceanogr., 54, 199-203, 1998.

Garcia, H. E., Locarnini, R. A., Boyer, T. P., and Antonov, J. I.: World Ocean Atlas 2005, Vol. 3: Dissolved Oxygen, Apparent Oxygen Utilization, and Oxygen Saturation. S. Levitus, Ed. NOAA Atlas NESDIS 63, US Government Printing Office, Washington, DC, 342 pp., 2006.

Glover, H. E., Prézelin, B. B., Campbell, L., Wyman, M., and Garside, C.: A nitrate-dependent Synechococcus bloom in surface Sargasso Sea water, Nature, 331, 161-163, 1988.

Gonzalez, N., Anadón, R., Mouriño, B., Fernández, E., Sinha, B., Escánez, J., and de Armas, D.: The metabolic balance of the planktonic community in the North Atlantic Subtropical Gyre: The role of mesoscale instabilities, Limnol. Oceanogr., 46, 946952, 2001.

Hagström, Å., Azam, F., Andersson, A., Wikner, J., and Rassoulzadegan, F.: Microbial loop in an oligotrophic pelagic marine ecosystem: possible roles of cyanobacteria and nanoflagellates in the organic fluxes, Mar. Ecol. Prog. Ser., 49, 171-178, 1988.

Hayase, K. and Shinozuka, N.: Vertical distribution of fluorescent organic matter along with $\mathrm{AOU}$ and nutrients in the equatorial Central Pacific, Mar. Chem., 48, 283-290, 1995.

Honjo, S., Dymond, J., Prell, W., and Ittekkot, V.: Monsooncontrolled export fluxes to the interior of the Arabian Sea, DeepSea Res. II., 46, 1859-1902, 1999.

Hu, J., Gan, J., Sun, Z., Zhu, J., and Dai, M.: Observed three-dimensional structure of a cold eddy in the southwestern South China Sea, J. Geophys. Res., 116, C05016, doi:10.1029/2010JC006810, 2011.

Jiao, N., Herndl, G. J., Hansell, D. A., Benner, R., Kattner, G., Wilhelm, S. W., Kirchman, D. L., Weinbauer, M. G., Luo, T., Chen, F., and Azam, F.: Microbial production of recalcitrant dissolved organic matter: long-term carbon storage in the global ocean, Nature Rev. Microbiol., 8, 593-599, 2010.

Jiao, N., Tang, K., Cai, H., and Mao, Y.: Increasing the microbial carbon sink in the sea by reducing chemical fertilization on the land, Nature Rev. Microbiol., 9, 75-75, 2011. 
Kirchman, D. L.: Incorporation of thymidine and leucine in the subarctic Pacific: Application to estimating bacterial production, Mar. Ecol. Prog. Ser., 82, 301-309, 1992.

Kirchman, D. L. and Wheeler, P. A.: Uptake of ammonium and nitrate by heterotrophic bacteria and phytoplankton in the subArctic Pacific, Deep-Sea Res. I., 45, 347-365, 1998.

Kwon, E. Y., Primeau, F., and Sarmiento, J. L.: The impact of remineralization depth on the air-sea carbon balance, Nat. Geosci., 2, 630-635, 2009.

Lee, S. and Fuhrman, J. A.: Relationships between biovolume and biomass of naturally derived marine bacterioplankton, Appl. Environ. Microb., 53, 1298-1303, 1987.

Mackey, M. D., Mackey, D. J., Higgins, H. W., and Wright, S. W.: CHEMTAX a program for estimating class abundances from chemical markers: application to HPLC measurements of phytoplankton, Mar. Ecol. Prog. Ser., 14, 265-283, 1996.

Maixandeau, A., Lefèvre, D., Karayanni, H., Christaki, U., Van Wambeke, F., Thyssen, M., Denis, M., Fernández, C. I., Uitz, J., Leblanc, K., and Queguiner, B.: Microbial community production, respiration, and structure of the microbial food web of an ecosystem in the northeastern Atlantic Ocean, J. Geophys. Res., 110, C07S17, doi:10.1029/2004JC002694, 2005.

Mann, K. H. and Lazier, J. R. N.: Biological-Physical Interactions in the Ocean, in: Dynamics of marine ecosystems, third edition, Blackwell Science, Cambridge, Massachusetts, 2006.

Mantoura, R. F. C. and Llewellyn, C. A.: The rapid determination of algal chlorophyll and carotenoid pigments and their breakdown products in natural waters by reverse-phase high-performance liquid chromatography, Anal. Chim. Acta., 151, 297-314, 1983.

McGillicuddy, D. J., Robinson, A. R., Siegel, D. A., Jannasch, H. W., Johnson, R., Dickey, T. D., McNeil, J., Michaels, A. F., and Knap, A. H.: Influence of mesoscale eddies on new production in the Sargasso Sea, Nature, 394, 263-266, 1998.

McGillicuddy, D. J., Anderson, L. A., Doney, S. C., and Maltrud, M. E.: Eddy-driven sources and sinks of nutrients in the upper ocean: Results from a $0.1^{\circ}$ resolution model of the North Atlantic, Global. Biogeochem. Cy., 17, 1035, doi:10.1029/2002GB001987, 2003.

Michaels, A. F. and Silver, M. W.: Primary production, sinking fluxes and the microbial food web, Deep-Sea Res., 35, 473-490, 1988.

Mouriño-Carballido, B.: Eddy-driven pulses of respiration in the Sargasso Sea, Deep-Sea Res. I., 56, 1242-1250, 2009.

Newton, P. P., Lampitt, R. S., Jickells, T. D., King, P., and Boutle, C.: Temporal and spatial variability of biogenic particles fluxes during the JGOFS northeast Atlantic process studies at $47^{\circ} \mathrm{N}$, $20^{\circ}$ W, Deep-Sea Res. I., 41, 1617-1642, 1994.

O'Brien, M. C., Melling, H., Pedersen, T. F., and Macdonald, R. W.: The role of eddies on particle flux in the Canada Basin of the Arctic Ocean, Deep-Sea Res. I., 71, 1-20, 2013.

Oschlies, A.: Can eddies make ocean deserts bloom?, Global. Biogeochem. Cy., 16, 53-1-53-11, 2002.

Oschlies, A. and Garçon, V.: Eddy-induced enhancement of primary production in a model of the North Atlantic Ocean, Nature, 394, 266-269, 1998.

Richardson, T. L. and Jackson, G. A.: Small phytoplankton and carbon export from the surface ocean, Science, 315, 838-840, 2007.
Rivkin, R. B. and Legendre, L.: Biogenic carbon cycling in the upper ocean: effects of microbial respiration, Science, 291, 23982400, 2001.

Robinson, C.: Heterotrophic bacterial respiration, in: Microbial Ecology of the Oceans, 2nd edn., edited by: Kirchman, D. L., Wiley, New York, 299-334, 2008.

Robinson, C. and Williams, P. J. le B.: Respiration and its measurement in surface marine waters, in: Respiration in aquatic ecosystems, edited by: del Giorgio, P. A. and Williams, P. J. le B., Oxford University Press, New York, 148-181, 2005.

Rosón, G., Álvarez-Salgado, X. A., and Pérez, F. F.: Carbon cycling in a large coastal embayment, affected by wind-driven upwelling: short-time-scale variability and spatial differences, Mar. Ecol. Prog. Ser., 176, 215-230, 1999.

Savoye, N., Benitez-Nelson, C., Burd, A. B., Cochran, J. K., Charette, M., Buesseler, K. O., Jackson, G. A., Roy-Barman, M., Schmidt, S., and Elskens, M.: ${ }^{234}$ Th sorption and export models in the water column: A review, Mar. Chem., 100, 234-249, 2006.

Siegel, D. A., McGillicuddy, D. J., and Fields, E. A.: Mesoscale eddies, satellite altimetry, and new production in the Sargasso Sea, J. Geophys. Res., 104, 13359-13379, 1999.

Su-Cheng, P., Chung-Cheng, Y., and Riley, J. P.: Effects of acidity and molybdate concentration on the kinetics of the formation of the phosphoantimonylmolybdenum blue complex, Anal. Chim. Acta., 229, 115-120, 1990.

Sweeney, C., Gloor, E., Jacobson, A. R., Key, R. M., McKinley, G., Sarmiento, J.L., and Wanninkhof, R.: Constraining global air-sea gas exchange for $\mathrm{CO}_{2}$ with recent bomb ${ }^{14} \mathrm{C}$ measurements, Global. Biogeochem. Cy., 21, GB2015, doi:10.1029/2006GB002784, 2007.

Sweeney, E. N., McGillicuddy, D. J., and Buesseler, K. O.: Biogeochemical impacts due to mesoscale eddy activity in the Sargasso Sea as measured at the Bermuda Atlantic Time-series Study (BATS), Deep-Sea Res. II., 50, 3017-3039, 2003.

Takahashi, M. and Bienfang, P. K.: Size structure of phytoplankton biomass and photosynthesis in subtropical Hawaiian waters, Mar. Biol., 76, 203-211, 1983.

Takahashi, T., Olafsson, J., Goddard, J. G., Chipman, D. W., and Sutherland, S. C.: Seasonal variation of $\mathrm{CO}_{2}$ and nutrients in the high-latitude surface ocean: a comparative study, Global. Biogeochem. Cy., 7, 843-878, 1993.

Van Heukelem, L. and Thomas, C. S.: Computer-assisted highperformance liquid chromatography method development with applications to the isolation and analysis of phytoplankton pigments, J. Chromatogr. A., 910, 31-49, 2001.

Yamashita, Y. and Tanoue, E.: Production of bio-refractory fluorescent dissolved organic matter in the ocean interior, Nature Geosci., 1, 579-582, 2008.

Zhai, W., Dai, M., Cai, W., Wang, Y., and Wang, Z.: High partial pressure of carbon dioxide and its maintenance mechanism in the Pearl River estuary, China, Mar. Chem, 93, 21-32, 2005.

Zhang, Y., Sintes, E., Chen, J., Zhang, Y., Dai, M., Jiao, N., and Herndl, G. J.: Role of mesoscale cyclonic eddies in the distribution and activity of Archaea and Bacteria in the South China Sea, Aquat. Microb. Ecol., 56, 65-79, 2009. 
Zhang, Y., Jiao, N., Sun, Z., Hu, A., and Zheng, Q.: Phylogenetic diversity of bacterial communities in South China Sea mesoscale cyclonic eddy perturbations, Res. Microbiol., 162, 320-329, 2011a.
Zhang, Y., Zhao, Z., Sun, J., and Jiao, N.: Diversity and distribution of diazotrophic communities in the South China Sea deep basin with mesoscale cyclonic eddy perturbations, FEMS Microbiol. Ecol., 78, 417-427, 2011b. 